Check for updates

Cite this: RSC Adv., 2019, 9, 30693

Received 7th August 2019

Accepted 12th September 2019

DOI: $10.1039 / c 9 r a 06145 b$

rsc.li/rsc-advances

\title{
DNA photo-cross-linking using a pyranocarbazole- modified oligodeoxynucleotide with a D-threoninol linker
}

\author{
Kenzo Fujimoto, (D) *a Tsubasa Yamaguchi, ${ }^{\text {* }}$ Takahiro Inatsugi, ${ }^{b}$ \\ Masahiko Takamura, (D) ${ }^{\text {I }}$ Isao Ishimaru, ${ }^{\text {b }}$ Ayako Koto ${ }^{\mathrm{b}}$ and Shigetaka Nakamura (D) ${ }^{\mathrm{a}}$
}

\begin{abstract}
An alternative photo-cross-linker having a $D$-threoninol skeleton instead of the 2 '-deoxyribose backbone in 3-cyanovinylcarbazole ( $\left.{ }^{\mathrm{CNV}} \mathrm{K}\right)$ was investigated to improve the photoreactivity of photo-cross-linkers; the photo-cross-linking rate of 3-cyanovinylcarbazole with $\mathrm{D}$-threoninol ( $\left.{ }^{C N V} \mathrm{D}\right)$ was found to be greater than that of ${ }^{C N V_{K}}$. Therefore, in this study, a novel photo-cross-linker having pyranocarbazole $\left({ }^{\mathrm{PC}} \mathrm{X}\right)$ and $\mathrm{D}^{\mathrm{-}}$ threoninol instead of the $2^{\prime}$-deoxyribose backbone in ${ }^{P C} X\left({ }^{P C X} D\right)$ was developed. The ${ }^{P C X} D$ in doublestranded DNA photo-cross-linked to a pyrimidine base at the -1 position of a complementary strand similar to ${ }^{\mathrm{PC} X}$. Furthermore, the photoreactivity of ${ }^{\mathrm{PCX}} \mathrm{D}$ was significantly higher than that of ${ }^{\mathrm{PC}} X$. The introduction of $D$-threoninol improved the reactivity of pyranocarbazole to cytosine, the use of ${ }^{P C X} D$ may extend the applicability of the photo-cross-linking reaction for DNA manipulation. In particular, this novel photo-cross-linker can contribute to the photochemical regulation of gene expression or biological events in a living cell.
\end{abstract}

\section{Introduction}

Photo-cross-linking reactions between biomolecules are used for various applications such as screening antigen interactions ${ }^{1}$ and improving detection sensitivity ${ }^{2}$ and the stability of biomolecular complexes. ${ }^{3}$ In particular, the use of DNA photocross-linking in the formation of a thymine dimer induced by UV-irradiation $^{4}$ and interstrand photo-cross-linking with psoralen $^{5}$ has been reported. In recent years, with the development of nucleic acid medicine and DNA nanotechnology, these have been used for the photochemical regulation of an antisense effect, ${ }^{6}$ improvement in stability of a DNA nanostructure, ${ }^{7}$ and other applications. Many photo-cross-linkers such as bromouracil $^{8}$ and benzophenone ${ }^{9}$ have also been reported. Among these, DNA photo-cross-linking via [2+2] photocycloaddition by psoralens $^{5}$ and coumarins ${ }^{10}$ is useful for detection, manipulation, and regulation of nucleic acids because photoreversible manipulation is possible. Compared to the enzymatic method, photo-cross-linking can be used under a wide range of conditions without the addition of reagents. Although the

${ }^{a}$ Department of Advanced Institute Science and Technology, Japan Advanced Institute of Science and Technology, Asahidai 1-1, Nomi, Ishikawa, 923-1292, Japan. E-mail: kenzo@jaist.ac.jp

${ }^{b}$ Advanced Materials Research Laboratory, Advanced Technology Research Department, In statute of Surface Science and Technology, NICCA CHEMICAL CO., LTD., 23-1, 4-Chome, Bunkyo, Fukui-City, 910-8670, Japan

† Electronic supplementary information (ESI) available. See DOI: 10.1039/c9ra06145b intracellular usage of photo-cross-linking has already been reported, these require UV-irradiation, which pose a limitation for use in living cells because of phototoxicity. We report pyranocarbazole $\left({ }^{\mathrm{PC}} \mathrm{X}\right)$ as a photo-cross-linker that can photo-crosslink to pyrimidine in complementary DNA or RNA strand under visible light. ${ }^{11}$ It was anticipated that his photo-cross-linker would accelerate the intracellular application of nucleic acid photo-cross-linking such as photochemical regulation of gene expression $^{12}$ and detection of RNA strand; ${ }^{13}$ however, photocross-linking using ${ }^{\mathrm{PC}} \mathrm{X}$ to cytosine requires photoirradiation for $1 \mathrm{~min}$, and it is necessary to speed up this process. Besides, the ribose backbone, $\mathrm{D}^{\text {-threoninol backbone, }}{ }^{\mathbf{1 4}}$ and serinol backbone ${ }^{15}$ have been reported as the backbone of the artificial nucleic acid. It was determined that 3-cyanovinylcarbazole modified D-threoninol $\left({ }^{\mathrm{CNV}} \mathrm{D}\right)^{\mathbf{1 6}}$ considerably accelerated the photo-cross-linking reaction with cytosine using the D-threoninol backbone ( $\left.{ }^{\mathrm{PCX}} \mathrm{D}\right)$ (Fig. 1). (a)

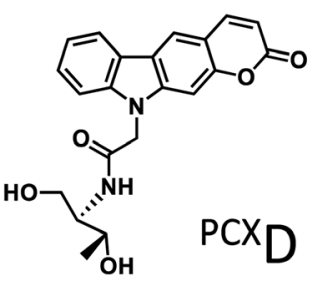

(b)

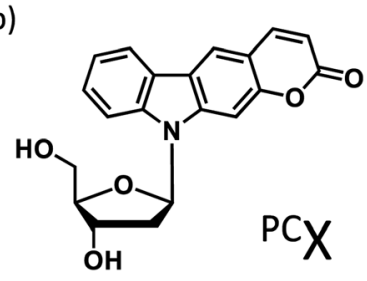

Fig. 1 Ultrafast photo-cross-linker (a) pyranocarbazole with Dthreoninol ( $\left.{ }^{\mathrm{PCX}} \mathrm{D}\right)$; (b) pyranocarbazole ( $\left.{ }^{\mathrm{PC} X}\right)$. 


\section{Results and discussion}

${ }^{\text {PCX }} \mathrm{D}$ was successfully synthesized according to the reaction scheme shown in Fig. 2. The ${ }^{\mathrm{PCX}} \mathrm{D}$ was phosphoramidited using a general method $^{17}$ after $5^{\prime}$ DMTr protection to synthesize the oligodeoxynucleotide (ODN) containing ${ }^{\mathrm{PCX}} \mathrm{D}$. The 9 mer ODN which has A, T, G, C having deoxyribose and ${ }^{{ }^{P C X}} \mathrm{D}$ having ${ }^{-}-$ threoninol was synthesized with an automated DNA synthesis machine, and then, it was deprotected using 28\% ammonium solution with a general method. After HPLC purification, it was analyzed using Matrix assisted Laser Desorption/Ionization (MALDI) analysis (Table 1).

First, we demonstrated the photo-cross-linking of ${ }^{\mathrm{PCX}} \mathrm{D}$ in double-stranded DNA. The duplex containing ${ }^{{ }^{\mathrm{PCX}}}{ }_{\mathrm{D}}$ was irradiated with $400 \mathrm{~nm}$ and analyzed using ultrahigh-performance liquid chromatography (UPLC). In the case of the pyrimidine base at the -1 position on the complementary ODN (cODN) strand, new peak identical to the photodimer appeared after photoirradiation, although such new peak did not appear in the case of the purine base at the -1 position on the cODN strand. The new peak was identified to photoadduct of PCXD-ODN(C) and its complementary strand (found $=5591.2$, calcd $[\mathrm{M}+\mathrm{H}]^{+}$ $=5591.0$ ) by MALDI-TOF-MS analysis. This suggests that the photo-cross-linking reaction occurred only in the case of the pyrimidine base at the -1 position on the cODN strand.

To analyze the photoreactivity of ${ }^{\mathrm{PCX}} \mathrm{D}$, the time course of the photoreaction was monitored, and then, the reaction rate constant was analyzed with the assumption of first-order reaction kinetics. As shown in Fig. 3, the reaction rate constant of ${ }^{\mathrm{PCX}} \mathrm{D}$ with cytosine is 4.3 -fold larger than that of ${ }^{\mathrm{PC}} \mathrm{X}$, suggesting that the relatively flexible $\mathrm{D}$-threoninol skeleton elevates the accessibility of the reactive double bond to the cytosine base on the complementary strand. The same effect was observed in the case of thymine as the target base of ${ }^{{ }^{P C X}} \mathrm{D}$; the reaction rate constant was 1.1-folds larger than that of ${ }^{\mathrm{PC}} \mathrm{X}$. The difference in the reactivity between the thymine and the cytosine bases decreased and the photoreactivity enhanced compared with
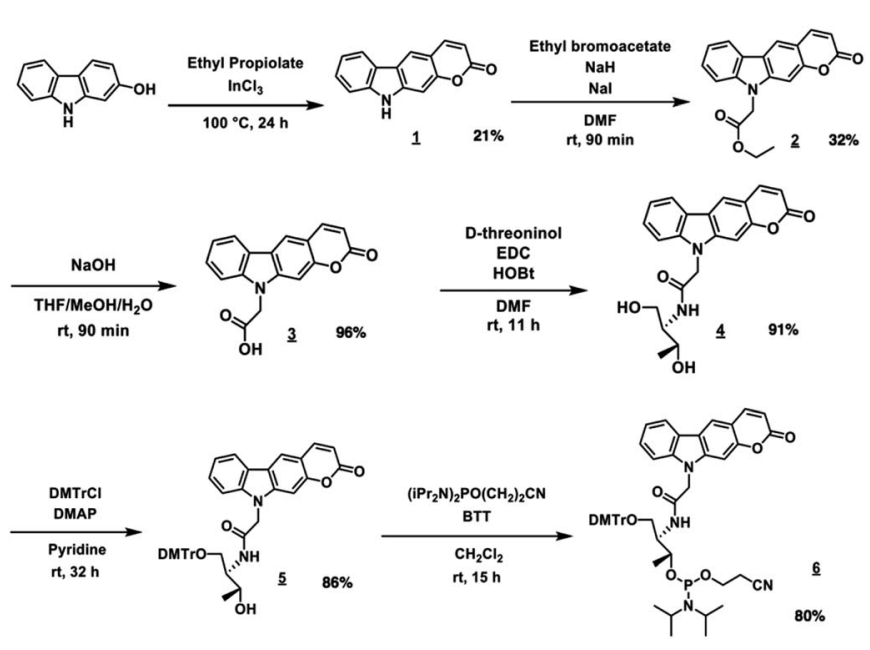

Fig. 2 Synthesis of ${ }^{P C X} D$ phosphoramidite.
Table 1 Sequence of ODN

\begin{tabular}{llll}
\hline Entry & Sequence $\left(5^{\prime}-3^{\prime}\right)$ & Calculated $[\mathrm{M}+\mathrm{H}]^{+}$ & Found \\
\hline${ }^{\mathrm{PCX}} \mathrm{D}-\mathrm{ODN}(\mathrm{C})$ & $\mathrm{TGCG}^{\mathrm{PCX}} \mathrm{DCCGT}$ & 2843.53 & 2843.60 \\
${ }^{\mathrm{PC}} \mathrm{X}-\mathrm{ODN}(\mathrm{C})$ & TGCG $^{\mathrm{PC}}$ XCCGT & 2823.31 & 2823.81 \\
${ }^{\mathrm{PCX}} \mathrm{D}-\mathrm{ODN}(\mathrm{T})$ & TGCA $^{\mathrm{PCX}}$ DCCGT & 2827.84 & 2828.94 \\
${ }^{\mathrm{PC}} \mathrm{X}-\mathrm{ODN}(\mathrm{T})$ & TGCA $^{\mathrm{PC}}$ XCCGT & 2807.52 & 2807.43
\end{tabular}

${ }^{\mathrm{PC}} \mathrm{X}$, which indicates that the use of ${ }^{\mathrm{PCX}} \mathrm{D}$ extends the applicability of the photo-cross-linking reaction for DNA manipulation.

To evaluate the duplex stability of $\mathrm{ODN}\left({ }^{\mathrm{PCX}} \mathrm{D}\right)$, the melting temperature $\left(T_{\mathrm{m}}\right)$ of the duplex consisting of $\mathrm{ODN}\left(\mathrm{A}^{\mathrm{PCX}} \mathrm{D}\right)$ and ODN(GT) was evaluated and compared with the duplex including ${ }^{\mathrm{PC}} \mathrm{X}$. The sigmoidal melting curve of $\mathrm{ODN}\left({ }^{\mathrm{PCX}} \mathrm{D}\right) /$ $\operatorname{ODN}(\mathrm{T})$ duplex was observed, which suggests $\mathrm{ODN}\left({ }^{\mathrm{PCX}} \mathrm{D}\right)$ and cODN(GT) formed a duplex structure. Then, we calculated the thermodynamic parameter from van't Hoff plots. ${ }^{18}$ The $\Delta S$ through $\mathrm{ODN}\left({ }^{\mathrm{PCX}} \mathrm{D}\right) / \mathrm{ODN}(\mathrm{T})$ hybridization was smaller than that of $\mathrm{ODN}\left({ }^{\mathrm{PC}} \mathrm{X}\right) / \mathrm{ODN}(\mathrm{T})$, suggesting that a relatively flexibility structure of ${ }^{{ }^{P C X}} \mathrm{D}$ inhibited the entropic loss via hybridization (Table 2). Therefore, ${ }^{\mathrm{PCX}} \mathrm{D}$ has a higher flexibility than ${ }^{{ }^{\mathrm{PC}} \mathrm{X}}$, and it induces a higher photo-cross-linking ability in cytosine than

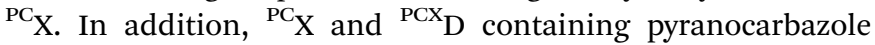
moieties have lower $T_{\mathrm{m}}$ values compared to ${ }^{\mathrm{CNV}_{\mathrm{K}}}$ and ${ }^{\mathrm{CNV}} \mathrm{D}$ containing 3-cyanovinylcarbazole moiety. When the polarity of pyranocarbazole $(\log P=1.12)$ and 3-cyanovinylcarbazole $(\log P$ $=1.35$ ) was examined, ${ }^{19}$ it was found that pyranocarbazole has

(a)

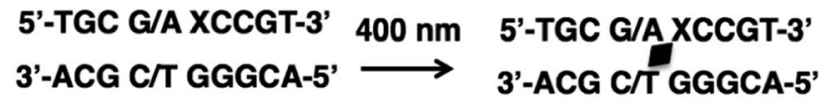

(b)
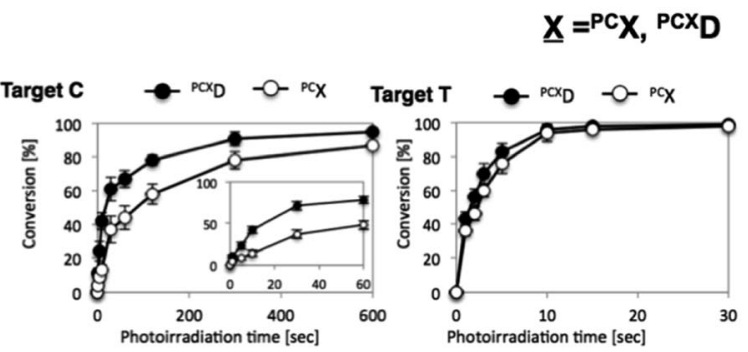

(c)

\begin{tabular}{ccc}
\hline & \multicolumn{2}{c}{ Reaction Rate Constants $k$} \\
Entry & C & $T$ \\
\hline${ }^{\mathrm{PCX}}$ & $0.032 \pm 0.006 \mathrm{~s}^{-1}$ & $1.2 \pm 0.1 \mathrm{~s}^{-1}$ \\
${ }^{\mathrm{PCX} D}$ & $0.142 \pm 0.011 \mathrm{~s}^{-1}$ & $1.3 \pm 0.2 \mathrm{~s}^{-1}$ \\
\hline${ }^{\mathrm{PCX}} /{ }^{\mathrm{PC}} \mathrm{X}^{*}$ & 4.3 & 1.1 \\
\hline
\end{tabular}

Fig. 3 Photo-cross-inking of ${ }^{P C X} D$ oligonucleotide in dsDNA. (a) Schematic of photo-cross-linking; (b) time course of photo-crosslinking to cytosine and thymine; inserted figure is an enlarged figure from $0 \mathrm{~s}$ to $60 \mathrm{~s}$. (c) Summarized reaction rate. 
Table 2 Thermodynamic parameter of each photo-cross-linker

\begin{tabular}{lllll}
\hline Entry & $\begin{array}{l}T_{\mathrm{m}} \\
{\left[{ }^{\circ} \mathrm{C}\right]}\end{array}$ & $\begin{array}{l}\Delta \Delta G_{37} \\
\left(\mathrm{kcal} \mathrm{mol}^{-1}\right)\end{array}$ & $\begin{array}{l}\Delta H \\
\left(\mathrm{kcal} \mathrm{mol}^{-1}\right)\end{array}$ & $\begin{array}{l}\Delta S \\
\left(\mathrm{cal} \mathrm{mol}^{-1} \mathrm{~K}^{-1}\right)\end{array}$ \\
\hline${ }^{\mathrm{PCX}} \mathrm{D}$ & 26 & -7.4 & -16.7 & -30.0 \\
${ }^{{ }^{\mathrm{PC}} \mathrm{X}}$ & 33 & -0.58 & -21.6 & -67.7 \\
${ }^{\mathrm{CNV}} \mathrm{D}$ & 29 & -7.3 & -33.8 & -85.6 \\
${ }^{\mathrm{CNV}} \mathrm{K}$ & 34 & -7.5 & -63.6 & -181.1 \\
\end{tabular}

a smaller $\log P$ and is hydrophilic. Therefore, it is considered that the $T_{\mathrm{m}}$ value of the duplex containing 3-cyanovinylcarbazole is high and the entropy loss is large because of the stacking between bases and hydrophobic interactions.

To evaluate the effects of the surrounding bases on the photo-cross-linking of ODNs containing ${ }^{\mathrm{PCX}} \mathrm{D}$, double strand with all variations of base pairs at the $-1,+1$ position of ${ }^{\mathrm{PCX}} \mathrm{D}$ and four different bases on the counter position to ${ }^{{ }^{\mathrm{PCX}} \mathrm{D} \text { in }}$ cODN were prepared; the conversion after $10 \mathrm{~s}$ of $400 \mathrm{~nm}$ irradiation was evaluated by UPLC. As shown in Fig. 4 , in the case of $\mathrm{T}$ at the $Z$ position in cODN, over $90 \%$ of the photo-cross-linking was obtained with $400 \mathrm{~nm}$ irradiation for $10 \mathrm{~s}$. In the case of $C$ at the $Z$ position, photo-cross-linking was observed. However, in the case of $\mathrm{A}$ or $\mathrm{G}$ at the $Z$ position, photo-cross-linking was not observed. These results indicate that the photo-cross-linking of ${ }^{\mathrm{PCX}} \mathrm{D}$ has similar pyrimidine selectivity as those of ${ }^{\mathrm{CNV}} \mathrm{K},{ }^{\mathrm{CNV}} \mathrm{D}$, and ${ }^{\mathrm{PC}} \mathrm{X}$. In addition, some differences in the reactivity were not observed among these duplexes, which indicated that the mechanism of effects such as local duplex stability and local electrostatic environment around the pyranocarbazole moiety remained does not affect the photo-cross-linking.

\section{Experimental}

\section{General}

${ }^{1} \mathrm{H}$ NMR spectra were measured on a Bruker AVANCE III 400 system. Mass spectra were recorded on a Voyager PRO-SF, Applied Biosystems and HRMS were measured on a Solarix-JA (Bruker) HPLC was performed on a Chemcosorb 5-ODS-H
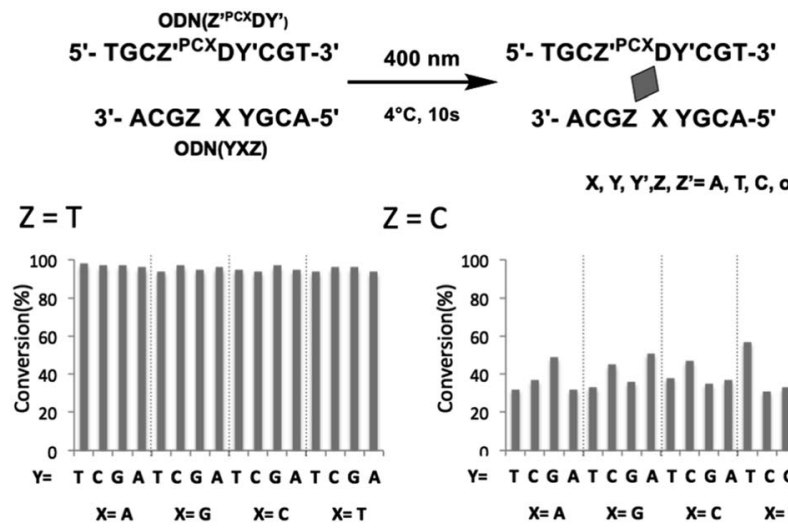

$\mathrm{Z}=\mathrm{C}$

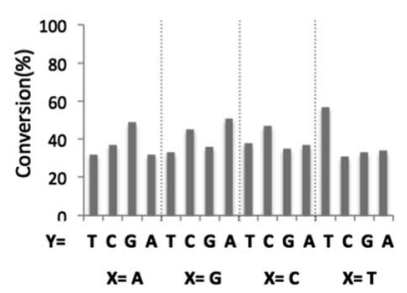

Fig. 4 Effect of surrounding base of ${ }^{P C X} D$ on its photoreactivity in dsDNA. $10 \mu \mathrm{M}$ DNA in $50 \mathrm{mM}$ cacodylate buffer ( $\mathrm{pH}$ 7.4) containing $100 \mathrm{mM} \mathrm{NaCl}$ was $400 \mathrm{~nm}$-irradiated for $10 \mathrm{~s}$ at $4{ }^{\circ} \mathrm{C}$. column with JASCO PU-980, HG-980-31, DG-980-50 system equipped with a JASCO UV 970 detector at $260 \mathrm{~nm}$. Reagents for synthesis for compound 1 to 5 were purchase from Aldrich, Wako, and TCI. Phosphoramidites of ${ }^{\mathrm{PCX}} \mathrm{D}$ were synthesized by the procedure as follows. Other phosphoramidite reagents for the DNA sysnthesizer such as A, G, C, T- $\beta$-cyanoethyl phosphoramidite, and CPG support were purchased form Glen research. Other oligonucleotides were purchased from Fasmac (Japan) and used without farther purification. The synthesized ODN having deoxyribose backbone except ${ }^{\mathrm{PCX}} \mathrm{D}$.

\section{Synthetic procedures}

Compound 2. Pyranocarbazole (1) (628 mg, $2.67 \mathrm{mmol}$ ) and $\mathrm{NaH}$ (60\% oil suspension, $320 \mathrm{mg}, 13.4 \mathrm{mmol})$ were solved in dry DMF $(10 \mathrm{~mL})$ and stirred for $20 \mathrm{~min}$ on ice under $\mathrm{N}_{2}$ atmosphere. Ethyl bromoacetate $(0.59 \mathrm{~mL}, 5.34 \mathrm{mmol})$ and NaI $(1.2 \mathrm{~g}, 8.0 \mathrm{mmol})$ was drop-wisely added over $30 \mathrm{~min}$ and stirred for $90 \mathrm{~min}$ at room temperature. Reaction mixture was poured onto water $(200 \mathrm{~mL})$ and extracted with chloroform and then dried over sodium sulfate. After removal of the solvent the residue was subjected to silica gel column chromatography $\left(\mathrm{CHCl}_{3}\right)$ to afford 2 (yellow solid, $\left.1.4 \mathrm{~g}, 4.6 \mathrm{mmol}, 32 \%\right) .{ }^{1} \mathrm{H}$ NMR $\left(400 \mathrm{MHz}, \mathrm{CDCl}_{3}\right) 8.06(\mathrm{~s}, 1 \mathrm{H}), 8.01(\mathrm{~d}, 1 \mathrm{H}, J=7.6 \mathrm{~Hz}), 7.8(\mathrm{~d}$, $1 \mathrm{H}, J=8.0 \mathrm{~Hz}), 7.44(\mathrm{~m}, 1 \mathrm{H}), 7.25(\mathrm{~d}, 1 \mathrm{H}, J=9.2 \mathrm{~Hz}), 7.24(\mathrm{~m}$, $1 \mathrm{H}), 7.13(\mathrm{~s}, 1 \mathrm{H}), 6.26(\mathrm{~d}, 1 \mathrm{H}, J=9.2 \mathrm{~Hz}), 4.91(\mathrm{~s}, 2 \mathrm{H}), 4.17(\mathrm{~m}$, $1 \mathrm{H}), 1.19$ (t, 3H, $J=7.2 \mathrm{~Hz}) .{ }^{13} \mathrm{C} \mathrm{NMR}\left(100 \mathrm{MHz}, \mathrm{CDCl}_{3}\right) 167.8$, $161.6,153.5,144.6,143.1,141.7,126.9,122.7,121.1,121.0$, 120.6, 119.7, 112.9, 112.7, 108.9, 96.1, 62.2, 45.0, 14.3. ESI-FTICR MS(HRMS) calcd for [M + H $]^{+}: 322.1073$, found: 322.1073 .

Compound 3. 2 (402 mg, $1.25 \mathrm{mmol}$ ) and $\mathrm{NaOH}(110 \mathrm{mg}$, $2.75 \mathrm{mmol})$ were solved in $\mathrm{THF} / \mathrm{MeOH} / \mathrm{H}_{2} \mathrm{O}(3: 2: 1,18 \mathrm{~mL})$ and stirred for $90 \mathrm{~min}$ at room temperature. After the addition of $1 \mathrm{~N} \mathrm{HCl}(150 \mathrm{~mL})$, reaction mixture was extracted with EtOAc $(150 \mathrm{~mL})$ and washed with $1 \mathrm{~N} \mathrm{HCl}$. Organic layer was dried over $\mathrm{MgSO}_{4}$ and evaporated to afford 3 (yellow solid, $1.2 \mathrm{~g}, 4.4 \mathrm{mmol}$, 96\%). ${ }^{1} \mathrm{H}$ NMR (400 MHz, DMSO-d 6 ) 13.17 (s, 1H), 8.50 (s, 1H), $8.19(\mathrm{~d}, 2 \mathrm{H}, J=9.2 \mathrm{~Hz}), 7.65(\mathrm{~s}, 1 \mathrm{H}), 7.59(\mathrm{~d}, 1 \mathrm{H}, J=8.4 \mathrm{~Hz}), 7.50$ $(\mathrm{m}, 1 \mathrm{H}), 7.30(\mathrm{t}, 1 \mathrm{H}, J=6.8 \mathrm{~Hz}), 6.36(\mathrm{~m}, 1 \mathrm{H}), 5.30(\mathrm{~d}, 2 \mathrm{H}) \cdot{ }^{13} \mathrm{C}$ NMR (100 MHz, DMSO-d $)_{6}$ 169.8, 160.6, 152.8, 145.4, 143.0, $141.6,126.5,121.9,120.4,120.3,120.1,120.0$, 112.0, 111.9, 109.7, 96.4, 44.2. ESI-FT-ICR MS(HRMS) calcd for $[\mathrm{M}+\mathrm{H}]^{+}$: 294.0760, found: 294.0762 .

Compound 4. 3 (156 mg, $0.53 \mathrm{mmol}$ ) and D-threoninol (111 mg, $1.06 \mathrm{mmol}$ ) were added to dry DMF (10 mL) containing 1-ethyl-3-(3-dimethylaminopropyl)carbodiimide hydrochloride (203 mg, $1.06 \mathrm{mmol}$ ) and 1-hydroxybenzotriazole (143 mg, 1.06 $\mathrm{mmol}$ ), and stirred for $11 \mathrm{~h}$ at room temperature. $\mathrm{NaCl}$ aq. soln was added and obtained precipitate was collected and dried under vacuum to afford 4 (yellow solid, $1.5 \mathrm{~g}, 4.1 \mathrm{mmol}, 91 \%$ ). ${ }^{1} \mathrm{H}$ NMR (400 MHz, DMSO-d $\left.{ }_{6}\right) 8.50(\mathrm{~s}, 1 \mathrm{H}), 8.18-8.21(\mathrm{~m}, 2 \mathrm{H})$, $8.00(\mathrm{~d}, 1 \mathrm{H}, J=8.8 \mathrm{~Hz}), 7.58-7.60(\mathrm{~m}, 2 \mathrm{H}), 7.50(\mathrm{t}, 1 \mathrm{H}, J=7.2$ $\mathrm{Hz}), 7.30(\mathrm{t}, 1 \mathrm{H}, J=7.2 \mathrm{~Hz}), 6.34(\mathrm{~d}, 1 \mathrm{H}, J=9.2 \mathrm{~Hz}), 5.17(\mathrm{~d}, 2 \mathrm{H}, J$ $=3.6 \mathrm{~Hz}), 4.72(\mathrm{~d}, 2 \mathrm{H}, J=4.2 \mathrm{~Hz}), 4.64(\mathrm{t}, 3 \mathrm{H}, J=4.2 \mathrm{~Hz}), 3.91$ (m, 1H), 3.65 (br, 1H), 3.47-3.54 (m, 1H), 3.36-3.41 (m, 1H), 1.02 $(\mathrm{d}, 3 \mathrm{H}, J=6.4 \mathrm{~Hz}) .{ }^{13} \mathrm{C}$ NMR (100 MHz, DMSO-d 6 ) 167.0, 160.6, 152.8 , 145.4, 143.1, 141.8, 126.4, 121.8, 120.3, 120.1, 120.1, 
119.9, 111.9, 111.8, 109.8, 96.3, 63.9, 60.5, 55.9, 45.6, 20.3. ESIFT-ICR MS(HRMS) calcd for $[\mathrm{M}+\mathrm{H}]^{+}$: 381.1444 , found: 381.1445. The molar extinction coefficient of ${ }^{{ }^{P C X}} \mathrm{D}$ is $4400 \mathrm{M}^{-1} \mathrm{~cm}^{-1}$.

Compound 5.4 (97.6 mg, $0.26 \mathrm{mmol}$ ), 4,4'-dimethoxytritylchloride (105 mg, $0.31 \mathrm{mmol}$ ) and 4-dimethyl-aminopyridine (105 $\mathrm{mg}, 0.31 \mathrm{mmol})$ in dry pyridine $(1 \mathrm{~mL})$ was stirred at room temperature for $18 \mathrm{~h}$. The reaction mixture was diluted with $\mathrm{CHCl}_{3}$, washed with $\mathrm{H}_{2} \mathrm{O}$ and organic layer was dried over $\mathrm{NaSO}_{4}$. After the removal of the solvent, residue was subjected to silica gel column chromatography $\left(\mathrm{CHCl}_{3}\right.$ with $0.1 \%$ TEA) to afford 5 (yellow solid, $0.63 \mathrm{~g}, 86 \%$ ). ${ }^{1} \mathrm{H}$ NMR (400 MHz, DMSO$\left.\mathrm{d}_{6}\right) 8.47(\mathrm{~s}, 1 \mathrm{H}) 8.17(\mathrm{t}, 3 \mathrm{H}, J=8.8 \mathrm{~Hz}) 7.59(\mathrm{~d}, 1 \mathrm{H}, J=8.4 \mathrm{~Hz})$, $7.57(\mathrm{~s}, 1 \mathrm{H}), 7.44(\mathrm{t}, 1 \mathrm{H}, J=8.8 \mathrm{~Hz}) 7.33-7.18(\mathrm{~m}, 10 \mathrm{H}), 6.78(\mathrm{t}$, $4 \mathrm{H}, J=8.8 \mathrm{~Hz}), 6.31(\mathrm{~d}, J=1 \mathrm{H}, 9.2 \mathrm{~Hz}), 5.16(\mathrm{~s}, 1 \mathrm{H}), 4.75(\mathrm{~s}, 1 \mathrm{H})$, $3.91(\mathrm{~d}, 2 \mathrm{H}, 6.0 \mathrm{~Hz}) 3.70(\mathrm{~s}, 6 \mathrm{H}), 3.11(\mathrm{t}, 1 \mathrm{H}, 6.4 \mathrm{~Hz}, 6.4 \mathrm{~Hz}), 2.93$ $(\mathrm{t}, 1 \mathrm{H}, 2 \mathrm{~Hz}, 6.0 \mathrm{~Hz}), 0.98(\mathrm{~s}, 1 \mathrm{H}) .{ }^{13} \mathrm{C} \mathrm{NMR}\left(100 \mathrm{MHz}, \mathrm{DMSO}_{-} \mathrm{d}_{6}\right)$ $167.0,160.5$, 157.9, 157.8, 152.8, 145.4, 144.4, 144.9, 143.0, $141.8,135.8,135.7,129.6$, 129.6, 127.6, 126.4, 126.3, 121.8, 120.3 120.1, 120.0, 120.0, 113.0, 112.9, 111.9, 111.7, 109.9, 96.4, 85.2， 79.1，64.8，62.9，54.9，54.1，45.7， 20.3. ESI-FT-ICR MS(HRMS) calcd for $[\mathrm{M}+\mathrm{H}]^{+}:$705.2571, found: 705.2568.

Compound 6. 5 (0187 mg, $0.28 \mathrm{mmol}), 0.25 \mathrm{M}$ solution of 5benzylthio-1H-tetrazole $(2.48 \mathrm{~mL})$ in dry $\mathrm{CH}_{2} \mathrm{Cl}_{2}(10 \mathrm{~mL})$ and 2cyanoethyl $N, N, N^{\prime}, N^{\prime}$-tetraisopropylphosphordiamidite $(540 \mu \mathrm{L}$, $0.62 \mathrm{mmol}$ ) were mixed under $\mathrm{N}_{2}$ for $3 \mathrm{~h}$. The crude mixture was dissolved in ethyl acetate. The solution containing 6 was washed with water, $\mathrm{NaHCO}_{3}$ aq. soln and brine. The organic layer was dried over $\mathrm{MgSO}_{4}$, and then filtered and the ethyl acetate was removed. The yellow foam $(0.21 \mathrm{~g}, 0.24 \mathrm{mmol}, 80 \%)$ was obtained and immediately used for DNA synthesis without further purification.

\section{Synthesis of oligodeoxynucleotide}

The oligonucleotides having ${ }^{P C X} \mathrm{D}$ were synthesized by a 3400 DNA synthesizer (Applied Biosystems) and purified by a HPLC system (JASCO PU-980, HG-980-31, DG-980-50, UV-970) with an InertSustainTM C18 column (GL Science, $5 \mu \mathrm{m}, 10 \times 150 \mathrm{~mm}$ ). Synthesized oligonucleotides was identified by MALDI-TOF-MS.

\section{Photoirradiation and UPLC analysis}

Photoirradiation was performed with an LED lamp (OminiCure, $400 \mathrm{~nm}, 8600 \mathrm{~mW} \mathrm{~cm}^{-2}$ ) on thermal cycler. The photoirradiated samples were analyzed with a UPLC system (Aquity, waters) equipped with BEH Shield RP18 column $(1.7 \mu \mathrm{m}, 2.1 \times 50 \mathrm{~mm}$, elution was with $0.05 \mathrm{M}$ ammonium formate containing $1-10 \%$ $\mathrm{CH}_{3} \mathrm{CN}$, linear gradient (10 min) at a flow rate of $0.4 \mathrm{~mL} \mathrm{~min}{ }^{-1}$, $\left.60{ }^{\circ} \mathrm{C}\right)$.

\section{Thermodynamic analysis of the hybridization}

Thermodynamic parameters were obtained according to a method in the literature: where TM is the melting temperature of duplex, $\Delta S^{\circ}$ is entropy and $\Delta H$ is the entropy of duplex formation, respectively. $R$ is the gas constant and CT is the total strand concentration. TM was measured at various concentrations of duplex in $50 \mathrm{mM}$ Na-cacodylate buffer ( $\mathrm{pH}$ 7.4) containing $100 \mathrm{mM} \mathrm{NaCl}$ by a spectrophotometer (V-630bio, Jasco) equipped with a temperature controller.

\section{Conclusions}

The ${ }^{\mathrm{PCX}} \mathrm{D}$ in double-stranded DNA photo-cross-linked to the pyrimidine base at the -1 position of the complementary strand was similar to that for ${ }^{{ }^{\mathrm{C}}} \mathrm{X}$, and the photoreactivity of ${ }^{\mathrm{PCX}} \mathrm{D}$ was significantly higher than that of ${ }^{\mathrm{PC}} \mathrm{X}$. The photo-crosslinking rate of ${ }^{\mathrm{PCX}} \mathrm{D}$ having $\mathrm{D}$-threoninol and cytosine was faster than that of ${ }^{{ }^{\mathrm{CC}} \mathrm{X}}$ and cytosine, the applicability of the photocross-linking reaction for DNA manipulation may be expanded by the use of ${ }^{{ }^{P C X}} \mathrm{D}$. We have already reported the importance of photo-cross-linking rate in photochemical antisense method in living cell and RNA FISH to E. coli 16S rRNA with a secondary structure. Therefore, this novel photo-crosslinker would contribute to the photoregulation of gene expression or biological events in living cells.

\section{Conflicts of interest}

There are no conflicts to declare.

\section{Acknowledgements}

This study was supported by Grant-in-Aid for Scientific Research (B) (No. 17H03085) of Japan Society of Promotion of Science.

\section{Notes and references}

1 D. S. Ziemianowicz, D. Ng, A. B. Schryvers and D. C. Schriemer, J. Proteome Res., 2019, 18, 934-946.

2 G. Fu and Z. Dai, Talanta, 2012, 97, 438-444.

3 M. M. Felczak, J. M. Sage, K. Huper-Kocurek, S. Aykui and J. M. Kaguni, J. Biol. Chem., 2016, 291, 4803-4812.

4 D. S. Goodsell, Oncologist, 2001, 6, 298-299.

5 F. P. Gasparro, P. A. Havre, G. A. Olack, E. J. Gunther and P. M. Glazer, Nucleic Acids Res., 1994, 22, 2845-2852.

6 M. Higuchi, A. Kobori, A. Yamayoshi and A. Murakami, Bioorg. Med. Chem., 2009, 17, 475-483.

7 A. Rajendran, M. Endo, Y. Katsuda, K. Hidaka and H. Sugiyama, J. Am. Chem. Soc., 2011, 133(37), 14488-14491.

8 C. D. Churchil, L. A. Eriksson and S. D. Wetmore, J. Phys. Chem. B, 2016, 120, 1195.

9 K. Nakatani, T. Yoshida and I. Saito, J. Am. Chem. Soc., 2002, 124, 2118.

10 H. Sun, H. Fan, H. Eom and X. Peng, ChemBioChem, 2016, 17, 2046-2053.

11 K. Fujimoto, S. Sasago, J. Mihara and S. Nakamura, Org. Lett., 2018, 20(10), 2802-2805.

12 K. Fujimoto, H. Yung and S. Nakamura, Chem.-Asian J., 2019, 14, 1912-1916.

13 K. Fujimoto, M. Hashimoto, N. Watanabe and S. Nakamura, Bioorg. Med. Chem. Lett., 2019, 29, 2173-2177.

14 H. Asanuma, T. Takarada, T. Yoshida, D. Tamura, X. Liang and M. Komiyama, Angew. Chem., Int. Ed., 2001, 40, 26712673. 
15 K. Murayama, Y. Tanaka, T. Toda, H. Kashida and H. Asanuma, Chemistry, 2013, 19, 14151-14518.

16 T. Sakamoto, Y. Tanaka and K. Fujimoto, Org. Lett., 2015, 17, 936-939.

17 S. L. Beaucage and M. H. Caruthers, Tetrahedron Lett., 1981, 22, 1859-1862.
18 J. L. Mergny and L. Lacroix, Oligonucleotides, 2003, 13, 515537.

19 OECD Guideline for testing of chemicals 117, http:// www.oecd.org/chemicalsafety/risk-assessment/1948177.pdf. 